\title{
ANALYZING THE ATATURK AIRPORT SERVICES
}

The paper discusses; It is the HUB of Ataturk Airport. as well as international and domestic flights at Ataturk Airport in terms of traditional and low-cost. The evolution of the airline begins with a summary of the cynologically. paper describes the physical and capacity characteristics of Ataturk Airport. It examines HUB types by dividing them into 3 pieces. In terms of HUB types, it specifies the type of Ataturk Airport. It shows the network structure of Ataturk Airport and analyzes the usage of Ataturk Airport about its market share. Ataturk Airport has a natural HUB quality thanks to its geographical location efficiency. To a large extent, he owes the network's breadth. By connecting Asia and Europe, it has the ability to provide the most transportation network in the world. Is examining the world-wide size of international and domestic airlines entering the airport. As well as the locations of Domestic airports connected by Ataturk Airport. Low-cost and traditional airlines. classifies local airlines and international air routes in low-cost and traditional aspects. Turkey offers to regulating the operation of the airport, airline flight frequencies into the table. Offers seating capacity of companies. This allows the possibility of determining the flight capacity. Regionally examines flight destinations. Again, the services preferred at Atatürk airport are shown on the table in proportions. At the end of the comparison, the results are examined.

\section{INTRODUCTION}

Since the birth of flight in 1903, air travel has emerged as a crucial means of transportation for people and products. The hundred-plus years following the invention of the first aircraft have brought about a revolution in the way people travel. The airline business is a major industry, relied upon by millions not only for transportation but also as a way of making a living. It is possible to categorize the history of this sector within early 20th Century "which is the airplanes were around the first few years, but flying was a risky endeavor not common place until 1925.", Mid-20th Century, late 20th Century and 2001.

At Mid-20th Century In 1938, the Civil Aeronautics Act established the Civil Aeronautics Board. This board served numerous functions, the two most significant being determining airlines' routes of travel and regulating prices for passenger fares. The $C A B$ based airfares on average costs, so because airlines couldn't compete with each other by offering lower fares, they competed by striving to offer the best quality service.

In the mid-1970s, Alfred Kahn, an economist and deregulation advocate, became chairman of the CAB. Around the same time, a British airline began offering exceptionally inexpensive transatlantic flights, awakening a desire for U.S.-based airlines to lower their fares. These influences led to Congress passing the Airline Deregulation Act of 1978, ushering in an era of unencumbered free market competition. The CAB disbanded a few years thereafter.

Post-deregulation, new carriers rushed into the market, and new routes directly connected cities previously accessible only via a string of layovers. Fares dropped as competition and the number of customers increased. A 1981 air traffic controllers strike brought a temporary setback to the growth, which continued throughout the 1980s. Some of the major carriers who had dominated the skies during the middle portion of the century, such as Pan American and TWA, began to collapse in the wake of competition. Such carriers disappeared completely following the Gulf War and subsequent recession of the early 1990s. Surviving airlines rode out the recession and returned to record profitability by the late 1990s.
In 2001, the industry dealt with the effects of another economic downturn, as business travel decreased substantially while labor and fuel costs increased. The events $9 / 11$ greatly magnified the airlines' issues, leading to a sharp decline in customers and significantly higher operating costs. Losses continued for years; the industry as a whole didn't return to profitability until 2006. A relatively stable period followed, although controversies arose over service quality and passenger treatment in terms of flight delays, particularly those involving planes waiting on the runway. In 2010 and 2011, the U.S. Department of Transportation issued a series of rules mandating that the airlines provide adequate modifications for passengers in extenuating circumstances.

After all this years, we always get better about flight technology and we are ready to have bigger steps of this subject. At this point I like to touch on meaning of the low fare carrier and HUB of airlines. Because of we will be discourse about the difference between low cost carriers and traditional carriers also concept of HUB for rest of the article.

Basically the low cost carriers cuts some of their services for to be more competitive against their competitor. Thus mostly makes benefits to clients and airlines. The point is provide the services to client above their needs.

In addition to all this Ataturk Airport is located on an area of $11,776,961 \mathrm{~m}^{2}$. The terminal with a capacity of 27.5 million passengers per annum has an area of $330.500 \mathrm{~m} 2,62,500 \mathrm{~m} 2$ domestic lines terminal and $268,000 \mathrm{~m}^{2}$ international lines terminal.

Ataturk Airport has three pists. Two concrete paved runways is $3000 \times 45$ meters. The other is $2600 \times 60$ meters and it is covered with Asphalt (Stone Mastic). The right of intention is owned by DHMI (State Airports Authority) and the terminal operator is TAV Holding.

\section{ATATURK AIRPORT AS A HUB}

\subsection{HUB types}

The HUB is network of the transportation which is located by very central for distant destinations. We can classification the HUB under 3 subjects, 
1. HUB type 1, American model; This model connected middle distance flight by middle distance flights.

2. HUB type 2. Europe model; within that middle distance flights link to long distance flights.

3. HUB type 3, Persian Gulf Region and Asian Side; in this model long distance flights consolidate within long distance flights.

One of the first to implement this model is Singapore Airlines, and now companies such as Emirates, Qatar Airways, and Etihad in the Gulf of Basra are taking the lead in this model.

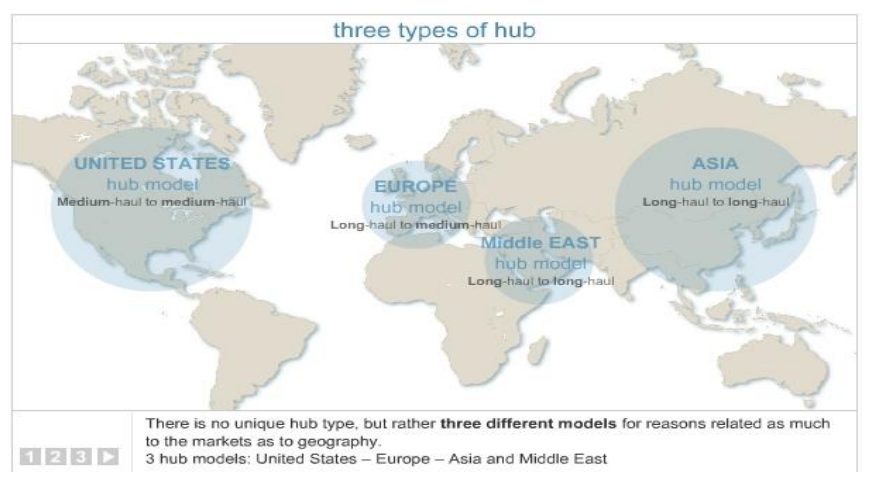

Fig. 1: Types of HUB in World

Looking at these models, we have once again realized what an advantageous position Istanbul, and therefore Turkish Airlines (THY) is.

When you position Istanbul as a hub, it is possible to implement a hybrid of the above three models:

Hub Type 1: between Europe and the Near East (Turkey interior lines may be added here)

Hub Type 2: Europe and North Africa to Southeast Asia, and finally;

Hub Type 3: Flights between the eastern shores of America and Southeast Asia can be connected via Istanbul.

\subsection{Ataturk Airport's Network}

Istanbul, as well as many other aspects, has a very advantageous position in the context of the commercial airline sector. It is almost a natural hub.

Istanbul is famous for linking Asia and European continents. It is seen as the most efficient transfer center in the world in terms of its geographical position. Atatürk Airport is among the most active airports in terms of international and domestic flights and passenger and cargo transportation. as seen in the above network; New York, Toronto, Houston, Chicago and Los Angles in the world is a very important place to connect with airports. South America is linked to Sao Paulo and Buenos Aires. In addition, every European country has connections with major airports. When we look at the Africa, there are at least 14 connection centers and Atatürk Airport has connection to Cape Town. The connection dates back to Tokyo in Asia. It is the only continental ocean with no connection.

Istanbul Atatürk Airport has risen from 13th place to 4th place in Europe in 10 years. Atatürk Airport, which is the 13th largest Hub of Europe in 2007, rose to 4th place in Europe with a growth of 591 percent in 2017. Istanbul Atatürk Airport, which is the 13th largest Hub connection in Europe in 2007, grew by $591 \%$ in 2017 and became the biggest airport in the top 20, making it the 4th largest Hub connection in Europe. Ataturk Airport is the 6th airport with the highest hub connection worldwide. In January 2017, the airport with the highest Hub connection in the world was Frankfurt Airport, while Istanbul Atatürk Airport ranked 6th after Amsterdam, Dallas, Paris and Atlanta.
Ataturk Airport is organizing operations in many countries of the world with many connections. Also domestic operations. By the end of 2017, a total of 63.7 million passengers were carried on the ATATURK airport, with an average of 19.4 million domestic flights and 44.3 million international flights.

Ataturk Airport broke the flight and passenger records all the time. The General Directorate of State Airports Authority stated that Atatürk Airport made 1,500 (one thousand five hundred) aircraft landing and departing in one day and declared that the record was broken all the time.

Ataturk Airport was breaking record by 2016. 236 planes departed and 245 aircrafts landed on domestic routes during the year. Outer lines, 513 aircraft departed, 506 aircraft landed. In total, the number of planes departing 749 , the number of descending planes 751 , the number of all aircraft reached 1500 . The number of passengers served on the same day was 156,941 . The number of passengers served with transit passengers reached 210,572 . Thus, Atatürk Airport, which is one of the busiest airports in the world, had a record breaking record for all time. The previous record was recorded as 1,478 landing - departure.

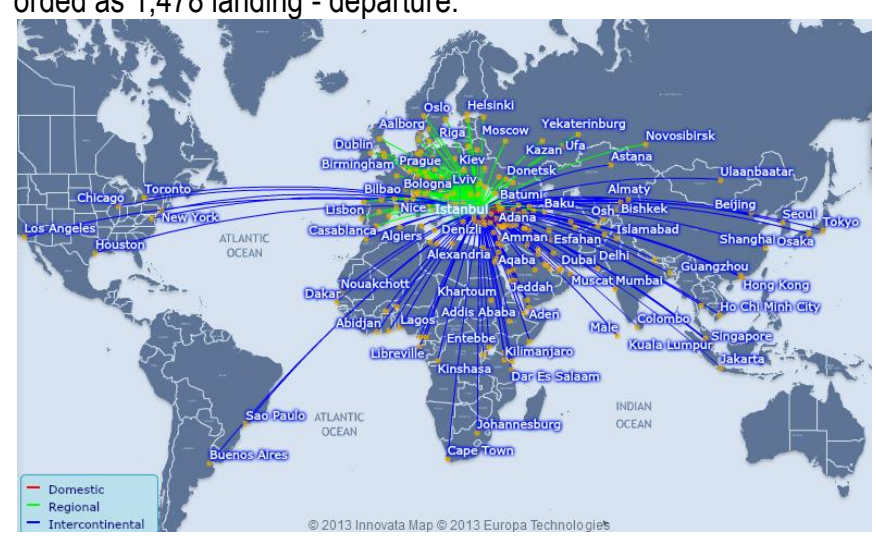

Fig. 2: Istanbul HUB Airline Route Map

Emphasized that this great success, despite explaining the state airspace operations, the attack of the live bomb on the International Terminal and the bad events like the July 15 betrayal, shows that the rise in Turkish civil aviation continues.

Approximately 700-730 planes fly up and down at Istanbul Atatürk Airport, and approximately 82,000 passengers are served. Ataturk Airport, which has all kinds of equipment that should be in a modern airport, also serves about 300 airline companies.

Turkey's biggest airport Istanbul Ataturk Airport and major airports in Europe, has also been praised in. Another feature is that Atatürk Airport's car park is the largest airport car park built under one roof in Europe. Monocle, the famous business and life magazine, also ranked Atatürk Airport as the only Turkish brand in the list of "Top 50 Travel Centers" in 2009-2010, and has also shown itself as a center of attraction for transit flights.

Also you can see below are the domestic airports to which Atatürk Airport connects.

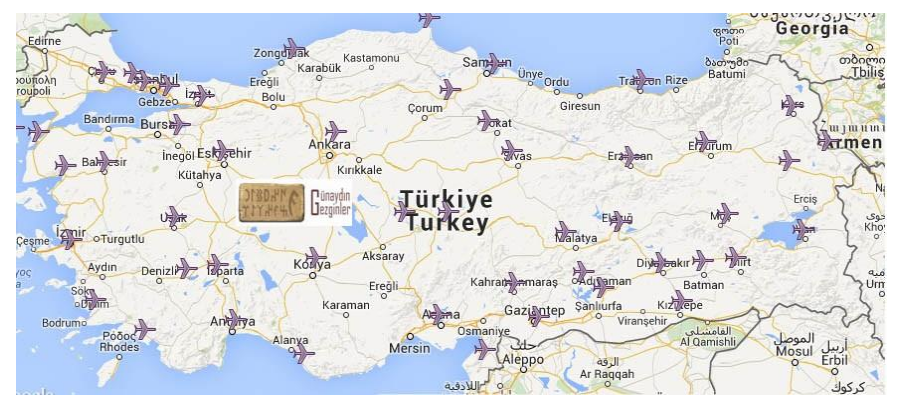

Fig. 3: Position of Turkish Airports 


\section{COMPARISON OF LOCAL AND INTERNATIONAL AIRPORT COMPANIES OPERATING TO ATATURK AIRPORT}

The list of airline companies that entering and leaving Ataturk Airport;

1.ADRIA AIRWAYS

2.AEGEAN AIRLINES

3.AEROFLOT RUSSIAN AIRLINES

4.AFRIQIYAH AIRWAYS

5.AIR ALGERIE

6.AIR ASTANA

7.AIR CANADA

8.AIR FRANCE

9.AIR MOLDOVA

10.AIR SERBIA

11.ALITALIA(COMPAGNIA AEREA ITALIANA)

12.AIR BALTIC

13.ARIANA AFGHAN AIRLINES

14.ASIANA AIRLINES

15.ATA AIRLINES (IRAN)

16.ATLAS JET INTERNATIONAL AIRLINES

17.AZERBAIJAN AIRLINES

18.BELAVIA, BRITISH AIRWAYS

19.BURAQ AIR

20.CHINA SOUTHERN AIRLINES

21.DELTA AIRLINES

22.DEUTSCHE LUFTHANSA AG

23.DNIPROAVIA AVIATION COMPANY

24.EGYPT AIR

25.EMIRATES, ETIHAD AIRWAYS

26.GHADAMES AIR TRANSPORT

27.GULF AIR COMPANY

28.IBERIA

29. UKRAINE INTERNATIONAL AIRLINE

30.IRAN ASEMAN AIRLINES

31.IRAQI AIRWAYS
Airways is ranked 13 th with 183 destinations. Finally, KLM is in 18th place with 185 destinations.

Onur Air, Pegasus Airlines, Atlas jet and Turkish Airlines are local and the rest is composed of international airways.

\section{COMPARISON OF TRADITIONAL AND LOW-COST AIRLINES WHICH OPERATING TO ATATURK AIRPORT}

First of all, getting a low-cost plane ticket does not mean you will travel in the queue. It does not mean that you will see a more unqualified treatment than the other roads. Low cost is not giving up on what you are entitled to, it is a system that has emerged for you to get services you do not need.

This system is based on a very simple logic. Let's look over the sample Pegasus known in Turkey. We note that the ticket prices of Pegasus airlines are generally the cheapest prices on the market. What does Pegasus do to make his tickets available at reasonable prices? This is not just for us to benefit, but also a sales strategy. The price of the ticket does not include baggage above a certain weight, online seat selection, food served in the airplane and water. Pegasus, which cuts down on these expenses, can sell tickets at much more affordable prices than other companies. All of this is of course not for you to live the most comfortable flight, but for you to travel without your pocket. Of course, there are products such as food, beverages, souvenirs and alcohol, which are sold on aircraft in aircraft prices if you wish. It is not necessary to think too much. For example, suppose you go to Europe by a 2-hour flight. Since the flight is not already very long, I am convinced that it will be more enjoyable to be able to bring the ticket to the appropriate price by reducing the services like food and beverages. Well, if you do not buy such a favorable ticket and say "Even water is paid", you have to make adjustments accordingly. The answer to the only economic situation is very good with people meet can be a shuttle to low cost because the airline or alias low cost carrier What questions aircraft usage in Turkey last 10 years, from the very widespread and that before seemed important to us.

I mentioned that Turkey in the form of low cost carriers serving the Pegasus. If you ask, "Which airline companies do you prefer abroad?"

Ryan air is one of the low cost airlines that you can choose for your flights. The Irish company is famous for its cheap tickets. Now that airplane use is almost a form of daily transportation, this company, named Ryanair, does not offer you a service on the plane, does not give you the right to suitcases and does not allow you to choose your seats yourself. All this may have been bad on the ears, but ticket prices are cheaper than water. Full student and traveler work. Another Low Cost firm is Wizz Air. From the eastern European company you can even match tickets at funny prices like 1 euro during promotional periods. If you do not mind limiting baggage and not eating on board, do not stop your tickets at all.

These airlines, also known as traditional airlines, full-service airlines or network carriers, serve on national, international and global markets with a wide geographical area, usually a centralsatellite network structure. These airlines serve different classes and have highly sophisticated service designs. Connected and long flights, large and complex fleet structure, sales offices with direct distribution and complex service processes such as sales and distribution through travel agencies require complex planning and operational systems.

International low cost airline companies that fly to Ataturk Airport include; AIR ALGERIE, AIR CANADA, AIR FRANCE, AIR BALTIC, ATA AIRLINES, AZERBAIJAN AIRLINES, EGYPT AIR, 
IBERIA, JAZEERA AIRWAYS, SWISS INTERNATIONAL AIR, UKRAINE INTERNATIONAL AIRLINE. The rest of the other airways mentioned in the third chapter are traditional international airline companies. Turkey is a traditional airline companies on the basis of Turkish airlines. Pegasus Airlines and Onur Air are low cost local airlines.

The capacity of the airline companies involved in the analysis study I have done is based on OAG and is based on the tariffs shared by the airline companies and excludes additional flights, charter flights and private jets.

The analyzes for domestic and international flights are as follows.

Tab. 1: Information of Istanbul Ataturk Airport

\begin{tabular}{|l|l|}
\hline Airport & Istanbul Ataturk Airport \\
\hline IATA Code & IST \\
\hline ICAO Code & LTBA \\
\hline Tracks (West to East) & $3.000 \mathrm{~m} \times 45 \mathrm{~m}(17 \mathrm{R} / 35 \mathrm{~L})$ \\
\hline & $3.000 \mathrm{~m} \times 45 \mathrm{~m}(17 \mathrm{~L} / 35 \mathrm{R})$ \\
\hline & $2.580 \mathrm{~m} \times 60 \mathrm{~m}(05 / 23)$ \\
\hline Number of passengers & 56,7 million \\
\hline \multicolumn{1}{|c|}{ Domestic } & 18,6 million \\
\hline International & 38,1 million \\
\hline
\end{tabular}

Tab. 2: Airlines and Market Share

\begin{tabular}{|l|l|l|l|}
\hline \multicolumn{5}{|c|}{ Istanbul Ataturk (IST) - Airlines and Market Share } \\
\hline Total Flights & Code & Frequency & Seating Capacity \\
\hline Turkish Airlines & TK & $75.8 \%$ & $75.8 \%$ \\
\hline Onur Air & $8 \mathrm{Q}$ & $5.7 \%$ & $6.0 \%$ \\
\hline Atlas Globalh & KK & $4.6 \%$ & $4.5 \%$ \\
\hline Lufthansa & LH & $0.8 \%$ & $0.8 \%$ \\
\hline Pegasus Airlines & PC & $0.8 \%$ & $0.8 \%$ \\
\hline Aeroflot & SU & $0.8 \%$ & $0.6 \%$ \\
\hline Iraqi Airways & IAW & $0.7 \%$ & $0.5 \%$ \\
\hline Saudi Arabian Airlines & SV & $0.7 \%$ & $0.7 \%$ \\
\hline Air France & AF & $0.5 \%$ & $0.4 \%$ \\
\hline Ukraine Airlines & PS & $0.5 \%$ & $0.4 \%$ \\
\hline Domestic Flights & Code & Frequency & Seating Capacity \\
\hline Turkish Airlines & TK & $76.1 \%$ & $73.8 \%$ \\
\hline Onur Air & $8 \mathrm{Q}$ & $13.1 \%$ & $14.8 \%$ \\
\hline Atlas Global & KK & $8.3 \%$ & $8.7 \%$ \\
\hline Pegasus Airlines & PC & $2.4 \%$ & $2.7 \%$ \\
\hline International Flights & Code & Frequency & Seating Capacity \\
\hline Turkish Airlines & TK & $75.6 \%$ & $76.6 \%$ \\
\hline Atlas Global & KK & $2.9 \%$ & $2.7 \%$ \\
\hline Onur Air & $8 Q$ & $2.2 \%$ & $2.3 \%$ \\
\hline Lufthansa & LH & $1.1 \%$ & $1.2 \%$ \\
\hline Aeroflot & SU & $1.1 \%$ & $0.8 \%$ \\
\hline Iraqi Airways & IAW & $1.1 \%$ & $0.8 \%$ \\
\hline Saudi Arabian Airlines & SV & $1.0 \%$ & $1.1 \%$ \\
\hline Air France & AF & $0.7 \%$ & $0.5 \%$ \\
\hline British Airways & BA & $0.7 \%$ & $0.7 \%$ \\
\hline Azerbaijan Airlines & J2 & $0.7 \%$ & $0.6 \%$ \\
\hline Ukraine Airlines & PS & $0.7 \%$ & $0.5 \%$ \\
\hline Aegean Airlines & A3 & $0.6 \%$ & $0.6 \%$ \\
\hline Air Astana & KC & $0.5 \%$ & $0.4 \%$ \\
\hline KLM & KL & $0.5 \%$ & $0.4 \%$ \\
\hline Middle East Airlines & ME & $0.5 \%$ & $0.4 \%$ \\
\hline Swiss & LX & $0.5 \%$ & $0.4 \%$ \\
\hline Egypt air & MS & $0.5 \%$ & $0.3 \%$ \\
\hline Mahan Air & W5 & $0.5 \%$ & $0.6 \%$ \\
\hline & & & \\
\hline
\end{tabular}

Tab. 3: Flights Destinations

\begin{tabular}{|l|l|l|}
\hline \multicolumn{3}{|l|}{ Istanbul Ataturk (IST) - Flights Destinations } \\
\hline Passenger Plane Destinations & Country & Airport \\
\hline Domestic & 1 & 40 \\
\hline Africa & 31 & 49 \\
\hline Asia-Pacific & 25 & 39 \\
\hline Central and Eastern Europe & 22 & 43 \\
\hline West Europe & 19 & 66 \\
\hline Latin America & 2 & 2 \\
\hline Middle Eastern & 11 & 29 \\
\hline North America & 2 & 10 \\
\hline Total & 113 & 278 \\
\hline Cargo Plane Destinations & Country & Airport \\
\hline Domestic & 0 & 0 \\
\hline Africa & 11 & 11 \\
\hline Asia-Pacific & 14 & 19 \\
\hline Central and Eastern Europe & 6 & 6 \\
\hline West Europe & 12 & 15 \\
\hline Latin America & 0 & 0 \\
\hline Middle Eastern & 9 & 9 \\
\hline North America & 1 & 2 \\
\hline Total & $\mathbf{5 3}$ & 62 \\
\hline Total Destinations & 113 & $\mathbf{2 8 4}$ \\
\hline
\end{tabular}

Tab. 4: Market Share For Service Type

\begin{tabular}{|l|l|}
\hline Istanbul Ataturk (IST) - Market Share For Service Type \\
\hline Service type & Ratio \\
\hline Full Serves & $98.4 \%$ \\
\hline Low-Cost Carrier & $0.9 \%$ \\
\hline Other (Cargo, Privet Jets vs) & $0.7 \%$ \\
\hline
\end{tabular}

Ataturk Airport; destinations, market share. When we look at the table, we see that local airline companies have a more intensive transaction volume than the specified ones. this is the case in international and domestic flights.

\section{CONCLUSION}

Istanbul, Turkey's economic and socio-cultural point of view the most important city as well as important geopolitical position between East and West it must have a place. Istanbul, the European Capital of Culture in 2010, population is one of the most crowded cities in Europe in terms of density. 14 In addition to the million population, more than 10 million tourists travel each year It falls to Istanbul. Istanbul Atatürk Airport takes its place at the most important entrance and exit point of this cosmopolitan city. Having become one of the world's number one hubs in aviation, geographical position and quality of service is an important center of attraction Istanbul Atatürk Airport, location, passenger flow speed and service Turkey's largest airport with not only quality, but also all of Europe's most praised and preferred airports one.

Today, 128 airline companies from Atatürk Airport making flights to 276 destinations in 110 countries of the world. 60 per year serving the nearest million passengers and becoming an important hub Atatürk Airport. Ataturk Airport, shortly growing today, Europe the fourth largest, the world's 13th airport has become. Which has the character of a social life using over 1,300 planes Ataturk Airport serves more than 160 passengers daily giving. Istanbul Atatürk Airport's HUB carrier is Turkish Airlines with a market share of $75 \%$.

Although there are three runways at Istanbul Atatürk Airport, only two runways can be used at the same time due to the distance between the runways, the runways being interdependent and the procedures to be applied in case of pass. On average, at one of the busiest hours of the square, a plane takes off in about a minute and a half. 
Looking at the overall tariff structure, it is seen that the arrival times of the Far East, Middle East and the domestic flights to the morning until 6:00 am (37 times in an intense hour) begin the day.

One and a half hours after the departure times, the first departure wave of morning hours begins.

This wave is predominantly in Europe with domestic lines, especially in Izmir, Ankara, Antalya and Adana. Most of the transit passengers from the Far East and the Middle East are actively connected to Europe during these times.

Since the main hubs in Europe are prohibited from flying at night, the first aircrafts depart from the points between 07:00 and 08:00 and arrive at Istanbul at 11:00.

The time between 10:00 and 11:30 is mainly for flights from Europe and domestic flights.

Arranged flights are prepared for departure, and the second flights to Europe within one and a half hours, followed by departures from America, Africa and the Middle East.

Evening Europe arrives in Istanbul for an effective connection to the Far East and Middle East departures as of midnight at midnight. If you look at the analyzes, Turkish Airlines makes the domestic and international flights at the highest rate of at least $75 \%$ and is a traditional airline company. This order is followed by the low cost firm Onur Air. At the international level is Atlas Global. 40 domestic airports are connected to the domestic routes for passenger carriage. Western Europe has made connections with 66 airports to 278 airports in total. In the case of cargo transportation, it serves 62 airports and connects with 284 destinations worldwide. Traditional airline companies are the ones that make the most flights to Ataturk airport with a rate of $98.4 \%$. Low cost carriers are operating at $0.9 \%$ at Ataturk Airport, including Onur Air and Pegasus Airlines.

\section{ACKNOWLEDGMENTS}

This paper is published as one of the scientific outputs of the project: "The research on virtual reality elements application: the significant improvement of simulator performance characteristics", ITMS: 26220220167“.

\section{BIBLIOGRAPHY}

1. Bilstein, Roger. Flight in America: From the Wrights to the Astronauts, Rev. ed. Baltimore: The Johns Hopkins University Press, 1994.

2. Davies, R.E.G. Airlines of the United States Since 1914. Washington, D.C.: Smithsonian Institution Press, 1972.

3. Heppenheimer, T. A. Turbulent Skies: The History of Commercial Aviation. New York: John Wiley \& Sons, 1995.

4. Securities Exchange Act Release No. 42208 (December 9, 1999), 64 FR 70613 (December 17, 1999) (the "Release")

5. See Letter from Matthew P. Fink, President, Investment Company Institute to, Arthur Levitt, Chairman, Securities and Exchange Commission, dated October 13, 1999.

6. International Air Transport Association (IATA), Fact Sheet: World Industry Statistics.

7. Air Transport Association of America (ATA), 2007 Economic Report.

8. Air Transport Association of America (ATA), Statement on the State of the Airline Industry, Statement for the Record of the Sub-committee on Aviation, Transportation and Infrastructure Committee, US House of Representatives, June 2004.

9. US Department of Transportation Bureau of Transportation Statistics, Form 41 Airline Traffic and Financial Reports.
10. G. Tsoukalas, "Convergence in the US Airline Industry: A Unit Cost and Productivity Analysis", MIT Master's Thesis, Department of Aeronautics and Astronautics, August 2007

11. J. Heimlich, "Outlook: Reaching for the Skies?", Air Transport Association of America, www.airlines.org. January 2007

12. G. Bisignani, "State of the Air Transport Industry", Address to the Annual General Meeting, International Air Transport Association, Vancouver, June 2006.

13. Statistics 58th Edition. IATA. Archived from the original on November 25, 2014.

14. Ferit Çağlar Gündüz, (22/01/2017). Düşük Bütçeli Hava Yolları Listesi. https://www.rotavrupa.com/low-cost-havayollari-listesi/

15. Vowles, Timothy M.; Lück, Michael (2016). "Low Cost Carriers in the USA and Canada". In Gross, Sven; Lück, Michael. The Low Cost Carrier Worldwide. New York: Routledge. ISBN 9781317025054.

16. Flybondi official website

17. Jet Smart official website

18. Novák Sedláčková, A. Kirschnerová, I. Fleet strategies in business aviation segment: homogeneity versus heterogeneity Vilnius: Vilnius Gediminas Technical University, 2015. - ISBN 978609-457-867-0.

19. Amit, R. ve Zott, C. 2001. Value creation in e-business. Strategic Management Journal, 22: 493-520.

20. Bieger, T., ve Agosti, S. 2005. Business models in the airline sector - evolution and perspectives. S. Auerbach, H. Baum \& W. Delfmann (Der.), Strategic management in the aviation industry. Köln: Kölner Wissenschaftsverlag.

21. Casadesus-Masanell R. ve Ricart, J.E. 2010. From strategy to business models and onto tactics. Long Range, Planning, 43, pp.195-215.

22. Tomova, A. et. all.: Ekonomika leteckých spoločností : pravidelná osobná doprava, Žilinská univerzita, 2017. - ISBN 97880-554-1359-4

23. Chesbrough, H. ve Rosenbloom, R.S. 2002. The role of the business model in capturing value from innovation: Evidence from Xerox Corporation's spin-off companies. Industrial and Corporate Change, 11(3):529-555.

24. Kliestik, T. Majerova, J. Lyakin, Alexander N.: Metamorphoses and semantics of corporate failures as a basal assumption of a well-founded prediction of a corporate financial health (ICESS 2015) : December 30-31, 2015, Paris, France. - Bellflower: Information Engineering Research Institute, 2015. - ISBN 978-161275-107-8.

25. Kuyucak, F. ve Sengur. Y. 2011. A comparative study of airlines operating in Turkish domestic market: Low-cost business model perspective. Journal of Business Review Cambridge, 19(1):6269.

26. Koralewski, G. Wrona, R. Dangerous occurrences at airports and monitoring them, Autobusy, 2017, R. 18, nr 12, ISSN 15095878

27. Poświata, A. Pietruszewski, P. The impact of airfield pavement evenness in the safety of the aircraft operations Autobusy, 2016 R. 17 , nr 12, ISSN 1509-5878

\section{Analyzing the Ataturk Airport Services}

Ever since we started air transportation, we have found new ways of traveling more safely everyday with technologies that push the limits of our imagination. Air transport has been connecting the continents with each other. Increased the volume of trade and made it easier to trade with the HUB 
concept. Airline companies are in the advertising competition while the safety of the flight is at the forefront. Each is more aimed at flying to the region and more often operating. At this point, the limits of competition have been so difficult that our lives have entered different levels of service, including low-cost and traditional. Low-cost airline companies aimed to reduce their costs by cutting some services in the airplane. such as the right to baggage being offered as a separate entitlement other than the ticket price. this service does not mean to cut off safety precautions regularly. Airlines continue to keep all security systems as strong as ever. The purpose of these discontinuities is to make as much of the costs of course as possible and to offer cheaper tickets to passengers. On the other hand, traditional airlines aim to keep passengers 'journeys as comfortable as possible by keeping passengers' services at a nearly luxurious level. Whichever is chosen depends on the needs of the traveller at the moment.

Of course, it is no surprise that air travel in the world is so popular. Despite the fact that it is the most expensive transportation vehicle compared to land, sea and railway transportation, It has always been the first preferred transportation facility by making the travel speed and the intercontinental passage very easy. This intensive preference certainly ensured the formation of HUB centers. HUB is a transfer center built on the world we mean. There are various transfer centers in the world. The most important feature for a HUB is the fact that it is the center of the transfer points. This ensures that the traveler or objects reach the point where they need to reach it strategically in the fastest and safest way without making too many transfers.

When we examine in this context as a HUB HUB is a natural Ataturk Airport in Turkey. Ataturk Airport is located on an area of 11,776,961 $\mathrm{m}^{2}$. The terminal with a capacity of 27.5 million passengers per annum has an area of 330.500 $\mathrm{m} 2,62,500 \mathrm{~m}^{2}$ domestic lines terminal and 268,000 $\mathrm{m}^{2}$ international lines terminal. Ataturk Airport has three pists. Two concrete paved runways is $3000 \times 45$ meters. The other is $2600 \times 60$ meters and it is covered with Asphalt (Stone Mastic). The right of intention is owned by DHMI (State Airports Authority) and the terminal operator is TAV Holding.
Ataturk Airport is a 60-year-old city that serves the nearest million passengers and is an important hub. Ataturk Airport, shortly growing today, Europe is the fourth largest, the world's 13th airport has become. Ataturk Airport serves more than 160 passengers daily giving.

Ataturk Airport has a great advantage due to its location which connects Asia and Europe. which Ataturk Airport is the 6th airport with the highest hub connection worldwide. Today, 128 airline companies from the Ataturk Airport make an entrance to and depart from Ataturk Airport with 276 destinations in 110 countries of the world. Among them airline companies internationally among the world's greatest; Lutfhansa, Air France, KLM and more. When we look at domestic airline companies, we see that HUB carrier is Turkish Airlines with a market share of $75 \%$. Onur Air, Atlas Global and Pegasus Airlines are other stakeholders. When we look at low-cost airline companies that operate at Ataturk Airport, we can say that there are few at the level that can be tried compared to the traditional airlines and domestic airlines. We can see that the biggest traditional local airline company is Turkish Airlines. Pegasus Airlines is the local airline company that has taken the lead in terms of low-cost service.

Market share for service type, the result is as follows; Traditional airline companies are the ones that make the most flights to Ataturk airport with a rate of $98.4 \%$. Low cost carriers are operating at $0.9 \%$ at Ataturk Airport, including Onur Air and Pegasus Airlines.

\section{Autorzy:}

MSc. Selma KIR - Istanbul University / Faculty of Logistics and Transportation, 34320 Avcilar , Istanbul, Turkey. e-mail: furkankuran@hotmail.com

prof. Ing. Andrej Novak, PhD - Zilinská univerzita v Žiline /University of Žilina, Univerzitná 8215/1, 01026 Žilina, Slovakia, e-mail: Andrej.Novak@fpedas.uniza.sk

JEL: 018 DOI: 10.24136/atest.2018.192 Data zgłoszenia: 2018.05.25 Data akceptacji: 2018.06.15 